\title{
Between Exclusion and Inclusion. Social Transgressions of Illiterate People in Western Culture
}

\begin{abstract}
The article attempts to explore the problem of functional illiteracy in the rich countries of the West. The author presents situations of adult illiterate people living in the world of Western culture who - deprived of the ability to read and write - surpass social and symbolic barriers in everyday life, struggling for survival and human dignity. The idiomatic phrase "the torture of Tantalus" symbolizes a person's pain resulting from the desire of owning things which are close but remain unobtainable. Through their complex biographies, the author indicates crucial moments in their lives: the decision to acquire reading and writing skills, and the pivotal point directly after the accomplished literacy course. If one deprives these people of professional assistance, it reduces their chances to materialise the expectations connected with reading and writing skills. The aim of the article is to draw attention to the phenomenon of adult illiteracy, which became a major task in educational policy and adult education also in many highly developed countries.
\end{abstract}

\section{Keywords:}

functional illiteracy, literacy, illiteracy, poverty, reading and writing courses

\section{INTRODUCTION}

The article discusses the social and symbolic limits faced every day by adults who cannot read and write. These people struggle to cross boundaries in their daily life, fighting for their dignity, as well as material and psychosocial survival in

Warsaw University of Live Sciences - SGGW, Poland. 
the world of the written word. Immersed in symbolic culture, they experience the "torment of Tantalus" (they feel tantalised), ${ }^{2}$ meaning that they suffer because they cannot participate in all areas of social life on a par with literate people.

Some illiterate people take the heroic effort to learn the skill of writing in their adulthood. Confronted with a variety of obstacles, they often cannot count on the understanding or support of their relatives and social environment. Isolated in their struggle, they frequently end up experiencing yet another educational (and life) failure.

Literacy is nowadays perceived as the most fundamental of human competences, indispensable both for daily functioning and social inclusion. Beyond any doubt, it is a prerequisite for the processes of lifelong learning, emancipation and the development of identity. As a constitutive value in itself, it cannot be subjected to the supremacy of instrumental goals, such as employability, competitiveness and adaptability, or even participation in social life and civic activity.

It is not about the functional nature of literacy, but about its potential to search for answers to existential questions. These may include supporting the individual on their path towards developing their subjective identity through reflection, understanding, interpretation and articulation; coming to terms with the freedom to plan one's biography and indeed one's life; and to learn more about the experience of self. In the culture of the written word, literacy can be identified with enculturation understood as "learning processes in which every individual has to participate in the life of society in order to acquire the ability to act in a way that is consistent with the local culture”3 (Kron, 2012, p. 41).

\section{LITERACY IN KNOWLEDGE SOCIETIES}

Nowadays, literacy is not just a cultural technique. Researchers treat it primarily as a manifestation of human activity expressed through personalised literacy practices which, on the one hand, include activities leading to writing the letters of the alphabet, and on the other hand, refer to "personalised literacy practices", meaning the

The phrase "the torment of Tantalus", or specifically in English the verb 'to tantalise', was coined based on the Greek mythology. It refers to the story of Tantalus, the king of Lydia, who displeased the gods and was severely punished by them. He could neither quench his thirst nor satisfy his hunger despite being submersed in water up to his neck, next to a fruit tree growing nearby. Additionally, a stone was placed over his head which could fall down on him at any time. Thus, the suffering of Tantalus, or the verb 'to tantalise', denotes something that is highly desirable, but always remains just out of reach.

3 Unless indicated otherwise, all the translations in the text come from its translator. 
values, beliefs, attitudes and feelings represented by those letters, and responsible for the development of interpersonal relationships and thus social structures (Barton \& Hamilton, 1998, p. 5). Literacy is a social practice, present in nearly all the spheres of the functioning of individuals and societies, i.e., in family life, in education, at work, during leisure time and in the public space. Nevertheless, the Western world has come to be divided into a "writing majority" and an alarmingly numerous "silent minority". In Western European countries, the latter accounts for a dozen or so percent of adult society (Przybylska, 2014, pp. 146-178).

A knowledge society recognises the ability to read and write as a skill of fundamental importance. Together with social norms, educational policies specify their catalogue of basic competences, as well as the level of knowledge and skills supposedly indispensable to every citizen. Failure to meet these standards turns a person into 'a loser', 'a weirdo', 'an intellectually disabled' or simply a 'stupid' person. One of the prevailing discourses today links the individual's level of knowledge and competence with their chance for a social and economic advancement and political participation.

Nearly equally widespread is the belief in the correlation between the level of education and qualifications of citizens and the economic development and overall well-being of society. A knowledge society forces its citizens to improve their knowledge and skills continuously. They will not otherwise be able to meet everyday life and work standards, and will consequently find themselves at the risk of social exclusion. The imperative of lifelong learning entails constant pressure and threat.

\section{ILLITERACY IN DISCOURSES ABOUT EXCLUSION AND INCLUSION}

Discourses on functional illiteracy are variable. Intertwined, they provide for a discontinuous diachrony. They overlap, opening ever broader contexts for analysis. ${ }^{4}$ Despite substantial research, the question of whether people with poor literacy skills are marginalised or socially excluded as yet remains unanswered. Difficulties arise already when an empirical distinction must be made between exclusion and inclu-

4 Teaching adults how to read and write is currently one of the political priorities of educational policies in the rich countries of the West. The scale of this phenomenon and its implications, both for individuals and societies, have forced governments to implement dedicated literacy programmes offering reading and writing courses, together with other forms of support for illiterate people. Research centres have also joined these efforts to help reduce the scale of functional illiteracy. 
sion. Every person living in a functionally diverse society belongs to at least a few societal subsystems. Their inclusion deficits in one system may be compensated for with their complete participation in the other system (Luhmann, 1995, p. 259).

By the mid-1990s, researchers were primarily focused on the negative experiences of illiterate adults in their family life, at school, in vocational education and social life. The discourse was almost exclusively limited to the discussion of literacy deficits. This trend was broken by Birte Egloff's report on narrative research conducted with illiterate people (1997). The German researcher paid attention to the strengths of functional illiterates who, despite their inability to read or write, managed quite well in the society of the written word.

Egloff's study presents many interviews in which participants of literacy courses clearly distinguished between their inadequate reading and writing skills, and their good performance in other areas. Many of them proudly emphasised the successes they achieved in life (Nuissl, 1999, p. 552). Contrary to stereotypical thinking, they were satisfied with their accomplishments and did not identify themselves as 'victims', despite the constant humiliation they experienced in this area. In fact, they did just the opposite - they perceived themselves as successful people and valued their professional and social competences which allowed them both to plan their career path and acquire additional qualifications in order to put their plan into action (Egloff, 2007, p. 77).

Nevertheless, most of the discourses pertaining to the issue of inclusion and exclusion perpetuate the opinion that illiterate people are condemned to a life of "multiple forms of subjective suffering and objective exclusion" (Schlutz, 2007, p. 18). This 'objective exclusion' is characterised by material poverty which both limits their chance of making a decent living, education, use of cultural goods and participation in social life, and prevents the illiterate from speaking up in the public space.

In this respect, researchers point to the combination of the following three factors: material, social and psychosocial, i.e., the actual social disadvantage, the marginalisation attributed to individuals by society and the marginalisation anticipated by the individuals themselves (Klocke, 2001, pp. 272-290). We should thus take into account that in highly developed Western societies, poverty is a social phenomenon which raises strong emotions, not as much in terms of the actual lack of material goods, but with respect to subjective experiences of those who do not meet the widespread standards and social norms. According to research on stigmatisation and emotional costs suffered by people labelled negatively for their poverty and progressing demoralisation, the subjective perception of poverty is a vital factor determining its implications (Sting, 2014, pp. 176-187). 
The need to show one's deficiencies in public, admitting to failure in meeting this basic social norm - i.e., to being 'different' - seems to be a greater challenge than functioning without the reading and writing skills in a symbolic culture based on the written word. If they do not find the courage to come out and disclose their educational deficits, then illiterate people agree to 'double exclusion': “Being actually excluded, they exclude themselves by refusing to participate because of negative personal or collective experiences in the family, among friends and colleagues” (Bolder, 2006, p. 30).

\section{"MULTIPLE FORMS OF SUBJECTIVE SUFFERING" IN THE BIOGRAPHIES OF ILLITERATE PEOPLE}

Illiterate people in modern Western societies experience the "torment of Tantalus". Just like the king who suffered from hunger and thirst despite having water and fruit within his reach, they go through similar torture. Immersed in a symbolic culture, they cannot avail themselves of the written word. Their drama is further exacerbated by their constant need for anonymity and fear of stigmatisation (Romberg, 1993, p. 15). They either live with the stigma, discredited in their environment and in the eyes of the public, or are at the risk of being humiliated when their deficiencies become known to the public (Goffman, 1963, p. 42). Their social contacts are marked by the constant dilemma: "To display or not to display, to tell or not to tell, to let on or not to let on, to lie or not to lie, and in each case, to whom, how, and where?” (Goffman, 1963, p. 78).

An illiterate person is a person who deviates from the standard generally accepted in societies which enforce the principle of compulsory education and perceive education as highly important. Hence, the tactic of avoiding situations marked by a higher probability of being exposed becomes a strategic element of life and an obsession for people who do not meet the literacy requirement. A stigmatised person, aware of the social reception of their deficiencies, concentrates all their energy on 'covering up' actions to "restrict the display of those failings most centrally identified with the stigma” (Goffman, 1963, p. 103). Such people also focus on developing and implementing an effective strategy to conceal their lack of competence. Over time, the stigma begins to control their life and illiteracy becomes a cross they must bear, ridden with guilt, shame and humiliation. They seek relief in hiding away from people or succumbing to an addiction.

Deficiencies evoke reaction in the both parties to an interaction. Following the mechanisms of stigmatisation, a stigmatised person begins to be perceived 
solely through the characteristic or condition responsible for their stigma. Charles H. Cooley explains how every individual forms an opinion of themselves based on their own impression of how other people see them or what they think about them (Konecki, 2014, p. 16). In individuals devoid of the fundamental social competence of literacy, this process, called the 'mirror of personality', must bring about a negative sensation. Christian Callo claims that when a suffering person is left on their own, they will live in anxiety and uncertainty which eventually will have a negative effect on their professional and private life. Such a person will be at the risk of living an unstable life, developing a phobia or neurosis and will suffer one defeat after another. If they are capable of taking any decision at all, then their choices will prove ineffective and inappropriate. Finally, they will reach the conclusion that they are 'a failure', 'a loser', not 'quite normal' (Callo, 2006, p. 330). Richard Wilkinson and Kate Pickett argue that the feeling of shame and humiliation always comes when someone feels "foolish, stupid, ridiculous, inadequate, defective, incompetent, awkward, exposed, vulnerable and insecure" (2011, pp. 57-58). Krzysztof T. Konecki adds as follows: "The social component in the causes of depression is rooted in the feeling of shame experienced when a person has a low self-esteem or no self-respect. Their shame is related to the fact that they have no safe social relationships, nor even a memory and thus ability to recall such relationships from the past” (Konecki, 2014, pp. 26-27).

The childhood stories of illiterate adults frequently reveal family pathologies: from lack of parents' interest in anything the child did to mental and physical abuse. "The situation at our family home was not good. That's why school was hard too. I have a disability certificate. My mother would always say: 'You're too stupid to boil water"”. Or: "I have to say I have six siblings. We would all do our homework at one table and help each other, but parents never did anything” (Klaus et al., 2011, p. 152). Indeed, empirical studies show that illiterate people live under constant emotional strain which affects their physical and mental health. Suicidal thoughts are not uncommon: “I don't have a job, I'm not fit for anything. I'd better end with this once and for all” (Döbert, 2009, p. 8).

Moreover, stress affects their family life: "My wife has to read everything to me. This is so humiliating” (Döbert, 2009, p. 9). Social relations are also stressful: "You meet a girl [...] and you tell her that you can’t write, and it means you're just stupid. You're simply a stupid man. You might be doing well, in fact you can do everything, but you can't write. To the society, you are a stupid person” (Döbert, 2009, p. 157). Stress is also present in professional life: "The competition is growing. I'm afraid they will fire me because I can't read and write, others are better than me” (Döbert, 2009, p. 9). 
Their economic situation, particularly when managing finances, is a neverending source of stress: “When I get payment orders, I don't react to them at all, and then I have to explain everything”; "I've been living on the dole for a long time and it is not enough money. I'm careful with every cent, but if something breaks down, like a washing machine or a vacuum cleaner, I don't know where to get the money from" (Ibidem). Every contact with any administrative office is stressful: "I said at the office that I can't read and write, but they still forget about it” (Ibidem, p. 10). "I'm totally dependent on the people at the office. I have to ask them everything. And later they tell me that they never said anything like that" (Ibidem). Stress is also associated with any kind of financial benefits and insurance: “I don't have an insurance. I don't sign anything, just in case. Who knows what I would sign?” (Ibidem). They feel wronged by the fate: "Sometimes I think that maybe this is because I was born preterm, in the seventh month, and my brain didn't develop well. You just ask yourself these questions: why, what for, what was the reason?” (Klaus et al., 2011, p. 153).

Moreover, empirical research points to the dysfunctional nature of coping strategies employed by illiterate people. They include the following: "taking no responsibility for solving the problem”, “delayed action/procrastination”, “thinking pessimistically of one's ability to solve the problem", "unproductive wishful thinking”, "long-term denial”, "long-term detachment”, or "long-term engagement in distracting activities” (Ibidem). Researchers characterise biographies of illiterate people as "a continuum [...] in the process of suffering" (Egloff, 1997, p. 120). Forced to struggle with multiple difficulties in their everyday life and absorbed in covering up their "failing”, they often cannot find the strength to make a personal change. And yet some of them do opt for this heroic act.

\section{MOTIVATION FOR LEARNING TO READ AND WRITE}

Based on existing studies, analysis and research projects, it is possible to examine the main types of motivation that push illiterate people to try (often yet once again) to eliminate their reading and writing deficits in adulthood. Their motives are strongly diversified, as they are rooted in everyone's individual life story. Some researchers even speak of the 'individuation of the problem' (Panagiotopoulou, 2001, p. 80). When telling their story, illiterate people refer to several motivational drivers: they want to do better at work, become independent, fight off their fear of situations in which reading and writing skills are required, help children with their homework, or open up to social life thus far limited because of their fear of being humiliated. 
However, research shows that functional illiterates decide to learn reading and writing most often only when they feel pressed to the wall. So long as they have a job and a source of income - even if it is not high - they do not take any steps towards improving their reading and writing skills (Klaus et al., 2011, p. 146). They come to terms with all the inconvenience associated with their deficits, perhaps because they "either do not believe that there are other people who also have such a problem, or that anyone can understand and help them” (Egloff, 1997, p. 151).

In the meantime, their well-designed survival strategy, which they have spent years developing, can be ruined at any time (e.g., death of a trusted person who helped them or a new job in which reading and writing is a necessity). Crisis situations, such as feeling threatened or major life changes, are the main incentive for learning for illiterate adults, or for adult learners in general. Nevertheless, next to dramatic experiences, some illiterates are also motivated by an ordinary need for a regular life, without hiding and constant fear of being exposed, the need to write a letter or read a newspaper (Egloff, 1997, p. 151).

\section{TURNING POINT: THE DECISION TO ENROL IN A COURSE}

Although it is indeed a 'torment' to illiterate people to function in the world of the written word, they usually find it very hard to sign up for a literacy course. Those who are enrolled often stress that it was at the behest of someone from their immediate social environment. However, there are cases in which it is the partners and other family members that hinder this decision or even object to any attempt on behalf of the illiterate to eliminate their deficits. One can only assume that in acting so they are motivated by their willingness to keep the illiterate person dependent on them.

Not without reason, the process of acquiring reading and writing skills is seen as the beginning of the path towards emancipation and an absolute pre-condition to one's autonomy. Participants in literacy course often point to their lack of faith in their own ability as a barrier to deciding to learn the alphabet. They talk of their doubts as to whether an adult can still learn anything, especially that they were not able to learn in childhood and adolescence what 'all' their peers managed to learn (Egloff, 1997, p. 156).

\section{CRITICAL POINT: COMPLETION OF A LITERACY COURSE}

Completing a reading and writing course is generally a major event in the life of adults who have lived with illiteracy in their adulthood. Everything changes for them and new opportunities arise. Their private and work situation may be different but, most of all, it is their view of themselves that evolves. Sometimes their 
success goes beyond their strength and imagination; in which case they are faced with the decision: what is next? How should they best make use of this hard-won treasure - the ability to read and write?

One German research project has provided significant results regarding the attitudes of adults who succeeded in eliminating their reading and writing deficits. It has done so by aiming to study the phenomenon of 'dwelling in the course', where people remain in institutional learning for an unusually long time, sometimes even for over 10 years. The project focused on people who were at first illiterate and who, over time, improved their reading and writing skills (Egloff et al., 2009, pp. 11-12). The researchers wanted to reconstruct the reasons why adult and now literate people delayed the moment of leaving the educational institution. Three groups of motives were recognised for their prolonged participation in the course.

Firstly, there were the motives included in the category called "enlarging the space of freedom". In their stories, the participants emphasised their relief and feeling of liberation that accompanied them in their learning process. 'Relief' because they decided to participate in the course, and 'liberation' because their participation in the course brought concrete benefits to their daily life. Paradoxically, despite their increased self-confidence, they did not leave the course which became a fixed element in their daily routine. It stabilised their newly obtained freedom and gave them the courage to engage in new forms of activity in other social fields. For example, one of the participants found in the course an inspiration for his social and political involvement. He gained popularity as a spokesperson for the illiterate. He explained his 'dwelling' on the course in terms of the satisfaction he would get from acting as an intermediary between the students and the teacher. His role in the course and activity for the illiterate outside the educational institution confirmed his positive opinion of himself.

The second group of motives for participating in the course for many years was qualified as "emancipatory aspirations". Those who chose to learn to read and write anticipated that literacy would expand their field of activity, giving them access to knowledge and a possibility of building a 'new identity'. One of the longterm participants pointed to a close link between learning and the prospect of going up in the social hierarchy: "I want to learn to make it better". Since she did not envisage the opportunity to improve her professional and social situation any time soon, she decided to continue the course, treating it as a guarantee of stability and something that organises her everyday life. Waiting for the promise of "emancipation through literacy" to come true, she chose to remain a part of a community of people sharing a similar fate. 
The third category includes motives related to "developing a new dependency", resulting from the specific relationship between the teacher and the student learning to read and write. Literacy teacher is perceived by learners as a confessor, a friend, an oracle, a guardian, a mentor and a guide to wisdom and a better world (Przybylska, 2014, p. 358). Setting oneself free from functioning under these 'caring wings' can be a difficult and long-lasting process.

In their conclusions, the researchers thus discussed what seems to be the weakest link in the educational endeavours addressed to low-skilled people from socially highly disadvantaged backgrounds. During the first two stages - i.e., that of "entering the course" (taking the decision to participate) and participating in the course - a multi-faceted pedagogical, psychological and therapeutic support is provided. In contrast, during the last stage of "exiting the course" - i.e., of becoming autonomous and self-reliant - the person completing the course is left entirely on their own. This approach may produce different results. Some students fear losing their feeling of safety and continue to dwell in the course, while others leave and become invisible (and thus unavailable to researchers interested in their further life) (Egloff et al., 2009, pp. 11-22).

\section{ADVOCATING FOR A PEDAGOGICAL SUPPORT FOR ILLITERATE PEOPLE AND GRADUATES OF LITERACY COURSES}

In being included more and more frequently by European countries in the academic curricula for educators and pedagogues as a separate specialisation, adult literacy is a particularly demanding field for professionals. It means working with people who have experienced different pathologies as children, exclusion from the school system as young people, and failures in their private and professional life as adults. It concerns people with low self-esteem, ashamed and fearful of yet another educational failure, alongside people with little experience in terms of learning who, as it happens, take the effort to learn to read and write sometimes without any support from or even against their social environment.

In their attempt to overcome their deficits, these people place a lot of faith in power of the ability to read and write. Some of them want to live a regular life, others to seek a better job, yet others would like to gain independence or prove to themselves that they are not worse than all the other people who learned to read and write at school. They also have differing ideas regarding the use of writing in their everyday life. 
Above all, they have enormous expectations of their teacher who is supposed to help them reach this milestone. The relationship between the literacy teacher and illiterate adult student is unique and has no equivalent in other areas of adult education. The students entrust to their teacher their innermost secrets and painful memories relating, for example, to the causes of their illiteracy. They want respect, understanding and support from their teacher who is often expected to 'make' them succeed, not only in mastering the skill of writing, but also in getting a grip on their life by helping them regain control, shed their shame and receive a chance to make free choices. After all, the process of teaching and learning to read and write is not just about the ability to read and write, but about a life in dignity and harmony as well as about personal development, empowerment and self-fulfilment.

The world of literacy is seen by functional illiterates as a great promise. Whether it comes true is entirely up to them and their decision what they will do with their literacy in everyday life. The fate of literacy course graduates shows that they should also be offered professional support after they complete their reading and writing course. This is a field for support groups, educational consultants, career counsellors, therapists, social workers and volunteers. Entangled in various social and individual contexts, illiteracy is a multi-layered phenomenon which may bring a variety of negative consequences. In the rich countries of the West, illiteracy has ceased to be treated as a problem of individuals. It has grown to the category of a social phenomenon whose structural nature forces the state and its institutions to take action.

\section{References:}

Arnold, U. (2009). Die Bedeutung biographieorientierter Forschung im Kontext von Alphabetisierung und Grundbildung, Report Zeitschrift für Weiterbildungsforschung, 4, pp. 2332.

Barton, D., \& Hamilton, M. (1998). Local Literacies. Reading and Writing in One Community. London: Routledge.

Bolder, A. (2006). Warum Lisa M. und Otto N. nicht weiter weitergebildet werden wollen. In: P. Faulstich, \& M. Bayer (Eds.), Lernwiderstände (pp. 26-38). Hamburg: VSA Verlag.

Callo, Ch. (2006). Modele wychowania. In: B. Śliwerski (Ed.), Pedagogika (pp. 277-390). Gdańsk: Gdańskie Wydawnictwo Pedagogiczne.

Carr, A. (2009). Psychologia pozytywna. Nauka o szczęściu i ludzkich siłach. Poznań: Zysk i S-ka.

Döbert, M. (2009). Alphabetisierung - Grundbildung - Gesundheit, Alfa Forum. Zeitschrift für Alphabetisierung und Grundbildung, 70, pp. 8-12.

Egloff, B. (1997). Biographische Muster „funktionaler Analphabeten”. Eine biographieanalytische Studie zu Entstehungsbedingungen und Bewältigungsstrategien von funktion- 
alem Analphabetismus. Frankfurt am Main: Deutsches Institut für Erwachsenenbildung.

Egloff, B. (2007). Biographieforschung und Literalität. In: A. Grotlüschen, \& A. Linde (Eds.), Literalität, Grundbildung oder Lesekompetenz? (pp. 70-80). Münster: Waxmann.

Egloff, B., Jochim, D., \& Schimpf, E.J. (2009). Zwischen Freiheitszugewinn, zugemuteter Emanzipation und Schaffung neuer Abhängigkeit - Kursbindung in der Alphabetisierung/Grundbildung, Report Zeitschrift für Weiterbildungsforschung, 4, pp. 11-22.

Goffman, E. (1963). Stigma: Notes on the Management of Spoiled Identity. Retrieved from: https://books.google.pl/books?id=zuMFXuTMAqAC\&printsec=frontcover\#v=snippet\& $\mathrm{q}=$ lie $\& \mathrm{f}=$ false 4

Klaus, A., Lohr, A.T., \& Vogel, Ch. (2011). Zusammenhänge zwischen Lernbiographie und Lernmotivation funktionaler Analphabeten und Analphabetinnen. In: Projektträger im DLR e.V. (Ed.), Zielgruppen in Alphabetisierung und Grundbildung Erwachsener (pp. 143-160). Bielefeld: W. Bertelsmann Verlag.

Klocke, A. (2001). Die Bedeutung von Armut im Kindes - und Jugendalter - Ein europäischer Vergleich. In: A. Klocke, \& K. Hurrelmann (Eds.), Kinder und Jugendliche in Armut. Umfang, Auswirkungen und Konsequenzen (pp. 272-290). Opladen: Leske \& Budrich.

Konecki, K.T. (2014). Socjologia emocji według Thomasa Scheffa. In: T. Konecki, \& B. Pawłowska (Eds.), Emocje w życiu codziennym. Analiza kulturowych, społecznych i organizacyjnych uwarunkowań ujawniania i kierowania emocjami (pp. 11-38). Łódź: Wydawnictwo Uniwersytetu Łódzkiego.

Kron, F.W. (2012). Pedagogika. Kluczowe zagadnienia. Gdańsk: Gdańskie Wydawnictwo Psychologiczne.

Luhmann, N. (1995). Soziologische Aufklärung, Die Soziologie und der Mensch. Opladen: Westdeutscher Verlag.

Nuissl, E. (1999). Lesen- und Schreibenlernen in der Erwachsenenbildung. In: B. Franzmann, K. Hasemann, D. Löffler, \& E. Schön (Eds.), Handbuch Lesen (pp. 550-567). München: Saur Verlag.

Panagiotopoulou, A. (2001). Analphabetismus in literalen Gesellschaften am Beispiel Deutschlands und Griechenlands. Frankfurt am Main: Europäischer Verlag der Wissenschaften.

Przybylska, E. (2014). Analfabetyzm funkcjonalny dorosłych jako problem społeczny, egzystencjalny i pedagogiczny. Toruń: Wydawnictwo Naukowe Uniwersytetu Mikołaja Kopernika.

Romberg, S. (1993). Wege Erwachsener in die Welt der Schrift. Opladen: Westdeutscher Verlag.

Schlutz, E. (2007). PISA für Erwachsene - Kompetenzerweiterung und zweite Chance? In: A. Grotlüschen, \& A. Linde (Eds.), Literalität, Grundbildung oder Lesekompetenz? (pp. 15-24). Münster: Waxmann.

Sting, S. (2014). Überleben lernen. In: M. Göhlich, Ch. Wulf, \& J. Zirfas (Eds.), Pädagogische Theorien des Lernen (pp. 176-187). Weinheim und Basel: Beltz Juventa.

Wilkinson, R., \& Pickett, K. (2011). Duch równości. Warszawa: Wydawnictwo Czarna Owca. 